\title{
Accessibility Political Adat (Study On Parmalim Indigenous Populations In North Sumatra)
}

\author{
Tonny Pangihutan Situmorang \\ Lecturer of Political Science Faculty of Social and Political Sciences, University of North Sumatra
}

\begin{abstract}
Indigenous peoples of Indonesia continues to be part of society's most vulnerable to the negative impacts of development resulting in structural poverty. It is also the point of the main problems faced by indigenous peoples in North Sumatra Parmalim. Emerging problems caused by the inability of people Parmalim present in the legislation in parliament and the process of policy by the government for various things like the identity they are still questionable. The author combines the phenomenological perspective and Ethnomethodology in the fight against the phenomenon of discrimination in society Parmalim position in the country. At the end of this paper the authors recommend the model solution specifically Parmalim community issues and indigenous peoples extensively through the reconstruction and change the system of recruitment of candidates of political parties, electoral systems and policies.
\end{abstract}

Keywords: discrimination, accessibility, politics, policy, elections

\section{INTRODUCTION}

The issue of fairness is an important issue that had been discussion in every state. Especially large countries, diverse cultures, religions, and customs resources like Indonesia. As a country with a democratic system which amounts to approximately 250 million people, is often its politics are still considering the impact of majority and minority are discriminatory.

According Theodorson and Theodorson (1979), Discrimination is unequal treatment of any individual, or group, based on something, usually categorical, or unique attributes, such as those based on race, ethnicity, religion or membership of social classes. The term is used to describe, the action of the dominant majority party in conjunction with a weak minority, so it can be said that their behavior is immoral and undemocratic. In that sense, discrimination is nature ${ }^{1}$.

On or aspects that can be visible (overt) of prejudice that is negative [negative prejudice] against an individual or a group. In this framework, we can also put forward a definition of the United Nations (UN), which read: "Discrimination includes any behavior only, which is based on a distinction made by nature or categorization of society, which has nothing to do with the ability of an individual or group ${ }^{2}$.

Indigenous peoples of Indonesia continues to be part of society's most vulnerable to the negative impacts of development. This condition is a continuation of the long history of discrimination and marginalization that have taken place before the colonial period to the present.

The rights of indigenous peoples who have different problems ignored by the State. Moreover, Indonesia as a unitary state has a number of diverse indigenous peoples. As; Samin community (Central Java), Dayak (Borneo), pemena (North Sumatra), Bedouin (Bantam), Parmalim (North Sumatra) to hundreds of indigenous people in Papua.

It is also the point of the main problems faced by indigenous peoples in North Sumatra Parmalim. Community Parmalim is one of the indigenous peoples and traditional native in North Sumatra, which spread mostly in Toba Samosir, Simalungun, Samosir, Humbang Hasundutan to Medan with the central region of religious are in Hutatinggi-Laguboti

Historically, public attendance Parmalim already there is a religious term was born in North Sumatra, whether Islamic, Christian, Catholic, Hindu or Buddhist. Public confidence in the grasp Parmalim already contain religious values that are noble and virtuous. Humans living in harmony with each other and the moral value between people and nature as well as human spirituality with his creator termed "Debata Mulajadi Nabolon" referred to as the ruler of the whole universe. ${ }^{3}$ Furthermore, the current carrying amount Parmalim community in

\footnotetext{
1 James Danandjaja, 2003, in"Diskriminasi Terhadap Minoritas Masih Merupakan Masalah Aktual Di Indonesia Sehingga Perlu Ditanggulangi Segera" Depok : Universitas Indonesia, Page 2-3.

${ }^{2}$ Ibid., Danandjaja, Page 3.
} 
North Sumatra is 5026 people or 0.14 percent of $12,985,075$ inhabitants. ${ }^{4}$

Parmalim Indigenous Peoples are still experiencing difficulties in defining itself. Do beliefs and rituals for which they believe in and practice religion or not. On the other hand, they also did not gain official recognition from the state about whether it pertained Parmalim trust or an indigenous community. As stated in the legislation population Number 23 Year 2006 concerning Population Administration article 1, paragraph 1 explains; Population Administration is planning activities and control circuit in the publication. Where to public services and the development of other sectors. Trip next state policy as stated in the explanation that the religion known as the Law does not incorporate Parmalim and other local beliefs as a religion in Indonesia. $^{5}$

For people often access Parmalim to have identity cards (KTP) is not affordable. Indonesian population obligation to have a legal identity, in this case the ID card, it becomes essential to be met considering the KTP associated with a variety of other legal identity issues as well as indirectly related to the issue of the welfare of the Law 23/2006 on Population Administration, especially in the Preamble 1 and Article 2 of the law stipulates that identity is the right of every resident of Indonesia.

Moreover, the political phenomenon in Indonesia requires legislative candidates must have a strong economic capital as well. Specifically, amid the political cost (cost politics) in Indonesia is relatively very high to make the workers, farmers and fishermen is hard to fight in the political contest. It is not talked about money politics are rife in every election, to campaign props such as billboards, banners and banners will be difficult provided the marginal groups. Not to mention, when the workers, farmers and fishermen have to compete with the incumbent legislative candidates with experience lead opinion, the media and the work program.

Then, to come forward as a candidate for a member of the community legislative Parmalim must also fill in the religion which is a dilemma to be equipped. The views of voters who became a

\footnotetext{
${ }^{4}$ Harian Kompas : "Kisah Penganut Agama Leluhur Batak yang Terasing di Negeri Sendiri" http://regional.kompas.com/read/2016/05/24/08191341/ki sah.penganut.agama.leluhur.batak.yang.terasing.di.negeri. sendiri?page=alldownloaded in 22 juni 2017 , at 19.50 wib.

${ }^{5}$ Wakhid Sugiyarto \& Asnawati, 2012, Dinamika Kepercayaan Parmalim di Kabupaten Samosir \& Toba Samosir Sumatera Utara, Jakarta : Kementerian Agama RI Badan Litbang dan Diklat Puslitbang Kehidupan Keagamaan Jakarta 2012, page 13.
}

constituent matter would automatically lead to stigma Parmalim with Sipelebegu (Satanic cult). As a result, the chances of the election of the community in every election Parmalim very little. If not selected the design of policies generated by the DPR / DPRD and the Government will be very unequal and exploitative of the local community, including community Parmalim. Interested to discuss accessibility It Researcher Indigenous Politics (Studies in Indigenous Peoples Parmalim In North Sumatra)

\section{RESEARCH METHODOLOGY}

This study is a qualitative research with critical paradigm. Where researchers collected data by interviewing. While this research is secondary data obtained by researchers of international journals, national journals, books and media releases. Research data collection is also done through a process of review of the documents or reports related to the focus of research. Researchers also collected various forms of qualitative data related to the accessibility of political, indigenous peoples, communities Parmalim and Elections also a useful document for the development of a deeper understanding of this research.

\section{RESULTS AND DISCUSSION}

\section{A.Discrimination against Parmalim}

Root of the problems faced by society is the absence of their Parmalim every policy implemented by the government. This is due to the ownership of the legal form of ID card identity is unclear. Inversely proportional to the rule of law in Indonesia, which requires that every resident ID card as an identity. In everyday life, the ID card can be a proof of identity of each community to access a wide range of policies and basic services provided by the government. ${ }^{6}$

Therefore, all the data of important documents such as the Family Card (KK), diplomas, marriage licenses until the residence permit submission process requires ID card. Not only that, when it will register as either the environment SOE employees or civil servants. Writing the column of religion recognized by the state became a necessity.

Furthermore, the curriculum in Indonesia requires that students take subjects and religious subjects. However, because Malim not recognized as a religion, the Parmalim usually be asked to choose another religion. Most typically between Islam and Christianity. Not only that indigenous peoples

${ }^{6}$ Lidwina Inge, Stepanus Makambombu and Dewi Novirianti, (2015), Kartu Tanda Penduduk dan Akses terhadap Layanan Dasar Studi Kasus di Kabupaten Bogor dan Kabupaten Sumba Timur, page.1-15. 
Parmalim also problematic in fulfillment of basic rights and access to public services.

Consequently reality that must be faced by the community Parmalim foment intolerance, discrimination and impoverishment structurally. In general, this problem is also become a major problem points to a group of local faiths in various regions in Indonesia. Parmalim society were marginalized by government policies. As a result, people are discriminated against by the various policies issued.

Not only this, but basically, the Parmalim community wants to fight antroposentis paradigm. However, they could not because it did not have access to touch politics and policy. The presumption devotee spirit, or in the popular lately with the term servant of satan makes them marginalized from political association. Moreover, the belief that they profess are very far from politics.

Let alone to power or make policy, their existence becomes a pressure groups do not even count. Not only that, the severity of the existence of the adherents of belief never even thought existed B.Accessibility Parmalim Politics

Accessibility Issues itself can be divided into physical accessibility and accessibility of nonphysical. Physical accessibility concerns on the availability of public space for indigenous peoples, such as; their chances of indigenous peoples into the open spaces are supported by regulatory legislation. Of course, a good rule concerning policy influencing policy involving all of society, including indigenous peoples to be legitimate in substance. There are countries most fundamental question is whether the state is entitled to exist; whether it can be justified that in every society there is a central agency with the authority to establish norms of behavior for members of the public and enforce obedience. The basic question regarding the law.

In Hurst (1974) said that accessibility is a measure of the ease (time, money, or effort) to make the transition between areas or regions within a system. Meanwhile, Edmonds (1994) stated that indicators of accessibility is a numeric value, which indicates the easy or difficult it is to get access to goods and services.

This accessibility also are not able to be reached by the community Parmalim. Therefore, In the midst of such great interest, the public interest Parmalim left behind and forgotten. Parmalim be positioned as an object in a political battle between good contesting political parties and candidates. So also with the interests Parmalim to give voting rights based on inadequate information, closed access to

${ }^{7}$ Franz Magnis Suseno, 2003, Etika Politik, Jakarta : PT.Gramedia Pustaka, page 55. politics itself. Even when, Parmalim Society began to participate in the race for a place in the parliament (legislature). Therefore, the involvement of indigenous peoples in any contestation of the election can be understood as a way of campaigning for the aspirations and demands of the grassroots who have not get a room. ${ }^{8}$

The absence of local communities in Indonesia, including Parmalim in each of the policies implemented by the government. Revised legislation elections every 5 years and also ignores the political rights of indigenous peoples.

Indeed, empirical each general election, especially after the reform. Indigenous peoples including Parmalim communities began to participate in the race for a place in the parliament (legislature). However, indigenous peoples' fight openly with people who already have a bonus since the beginning of the social, economic and political becomes unjust stage in a political contest.

Therefore, the involvement of indigenous peoples in any contestation of the election can be understood as a way of campaigning for the aspirations and demands of the grassroots who have not get a room. Making the parliament as a sparring room and exam room to push to the surface issues of land and the rights of indigenous peoples were ignored. ${ }^{9}$

Moreover, the political phenomenon in Indonesia requires legislative candidates must have a strong economic capital as well. Specifically, amid the political cost (cost politics) in Indonesia is relatively very high to make the workers, farmers and fishermen is hard to fight in the political contest. It is not talked about money politics are rife in every election, to campaign props such as billboards, banners and banners will be difficult provided the marginal groups. Not to mention, when the workers, farmers and fishermen have to compete with the incumbent legislative candidates with experience lead opinion, the media and the work program.

Then, to come forward as a candidate for a member of the community legislative Parmalim must also fill in the religion which is a dilemma to be equipped. The views of voters who became a constituent matter would automatically lead to stigma Parmalim with Sipelebegu (Satanic cult). As

${ }^{8}$ Media Kumparan, Andrea Baharamin in Review Kongres Aliansi Masyarakat Adat Nusantara (AMAN) III di Medan 15 Maret 2017 "Berselancar di Parlemen" https://kumparan.com/andre-barahamin/berselancar-diparlemen, downloaded in 17 juni 2017, at 19.35 wib. ${ }^{9}$ Media Kumparan, Andrea Baharamin dalam Review Kongres Aliansi Masyarakat Adat Nusantara (AMAN) III di Medan 15 Maret 2017 "Berselancar di Parlemen" https://kumparan.com/andre-barahamin/berselancar-diparlemen, downloaded in 17 juni 2017, at 19.35 wib. 
a result, the chances of the election of the community in every election Parmalim very little. If not selected the design of policies generated by the DPR / DPRD and the Government will be very unequal and exploitative towards local communities including Parmalim society.

\section{C.Received Indigenous Parmalim}

Of course this is a progress for the society Parmalim mainly to do with democracy. Therefore, the post-reform electoral laws routinely revised to follow the dynamics of society to ensure the principle of representation, accountability and legitimacy of greater democratization. Start of Act No. 3 of 1999 as the regulations for the election in 1999, Law No. 3 of 2003 as a reference for the 2004 elections, the Law number 10 of 2008 as guidelines for the 2009 election and Law No. 2 of 2011 as the legal basis for the 2014 elections and the law No. 7 year 2017 to 2019.elections

Democracy in Indonesia needs to be repaired, amid political accessibility Parmalim society is irrelevant in the middle of their inability to occupy seats in parliament if it must compete openly with system one man one vote amid the economic imbalance legislative candidates. ${ }^{10}$ Therefore, competition between the public Parmalim against entrepreneurs, military retirees and professionals who enter into politics is a democratic space that is not fair.

Therefore, at the end of this article seeks floated the idea to the public Parmalim Received Seat in Parliament for the sake of their political accessibility. Where to improve the quality of democracy in Indonesia fulfillment of political rights not only as a right to choose, but also the opportunity of every citizen to become a member of Parliament through a Seat Received or allocation of permanent seats for indigenous peoples.

Like a special seat for the Maori, New Zealand's indigenous tribes. The chair ensures the Maori people who have something select choose to enroll and vote on a separate ballot box with a direct voice for New Zealand's Parliament. The concept of reserved seats have been introduced since 1867 and still exists today as a hallmark of New Zealand's constitutional democracy, in spite of the introduction of proportional representation. ${ }^{11}$

Therefore, one solution to improving the quality of elections has a principle of

\footnotetext{
${ }^{10}$ Farzana Bari, 2002, Representation in Legislatures: The Way Forward, Ministry and Development. January. Page 11.

${ }^{11}$ Jeremy Sparrow, 2012, "The Truth about the Maori Seats "A dissertation submitted in partial fulfilment of the degree of Bachelor of Laws (Honours) at the University of Otago, Dunedin, New Zealand.
}

representativeness, fairness and openness are all Indonesian citizens have equal access to influence policy. Moreover, DPR or DPRD as an executive agency that has a legislative function, budgetary, and oversight will certainly support the ideals of the welfare of all the people of Indonesia.

\section{AKNOWLEDGEMENT}

It must be acknowledged political passion to provide public accessibility Parmalim in parliament is not only limited in the management of political parties and candidates in the election. Of course this condition is irrelevant in the middle of their disability if it must fight openly. Therefore, comparing the Parmalim community with people who from the beginning has experienced the democratic political contest is not a fight. Why, it must be recognized Parmalim Society is far behind the social, economic and political. So automatically Parmalim Society will lose any elections that are free and open.

That's why System Reserved Seat offered not just a formula writer try alone. This system has been tested academically and empirically well as for resolving discrimination. In many countries in the developed and the developing world, such as; Belgium, Croatia, Argentina, Afghanistan and Cyprus have applied Reserved Seat and overcome problems related to discrimination. Substantially Reserved Seat applied these countries aims to ensure people who are discriminated against and marginalized are represented in parliament have a say in every policy and political decisions.

Certainly the presence of system Reserved Seat Indigenous Peoples next election is not an empty concept. Reserved Seat of Indigenous Peoples in the Parliament is the Indonesian efforts to make sure that equality, affirmation, and justice actually be present in the discrimination faced by indigenous peoples over the years. In order for all interests and identities represented in parliament as the mandate of Pancasila and the 1945 Constitution.

\section{REFERENCES}

\section{Buku :}

Magnis, Franz Suseno, (2003), Etika Politik, Jakarta : PT.Gramedia Pustaka.

\section{Jurnal :}

Bari, Farzana, (2002), Representation in Legislatures: The Way Forward, Ministry and Development. January.

Danandjaja, James, (2003) "Diskriminasi Terhadap Minoritas Masih Merupakan Masalah 
Aktual Di Indonesia Sehingga Perlu Ditanggulangi Segera" Depok : Universitas Indonesia.

Inge, Lidwina Stepanus Makambombu and Dewi Novirianti, (2015), Kartu Tanda Penduduk

dan Akses terhadap Layanan Dasar Studi Kasus di Kabupaten Bogor dan Kabupaten Sumba Timur,

Sparrow, Jeremy (2012), "The Truth about the Maori Seats"A dissertation submitted in partial fulfilment of the degree of Bachelor of Laws (Honours) at the University of Otago, Dunedin, New Zealand.

Sugiyarto, Wakhid \& Asnawati, 2012, Dinamika Kepercayaan Parmalim di Kabupaten

Samosir \& Toba Samosir Sumatera Utara, Jakarta : Kementerian Agama RI Badan Litbang dan Diklat Puslitbang Kehidupan Keagamaan Jakarta 2012.

\section{Media :}

Media the Jakarta times : "Parmalim dalam Bingkai NKRI' http://www.thejakartatimes.com/parmalimdalam-bingkai-nkri/ downloaded in 3 juni 2017 at 11.41 wib.

Harian Kompas : "Kisah Penganut Agama Leluhur Batak yang Terasing di Negeri Sendiri" http://regional.kompas.com/read/2016/05/24/081913 41/kisah.penganut.agama.leluhur.batak.yang.terasin g.di.negeri.sendiri?page $=$ alldownloaded in 22 juni 2017, at 19.50 wib.

Media Kumparan, Andrea Baharamin dalam Review Kongres Aliansi Masyarakat Adat Nusantara (AMAN) III di Medan 15 Maret 2017 "Berselancar di Parlemen" https://kumparan.com/andrebarahamin/berselancar-di-parlemen, downloaded in 17 juni 2017, at 19.35 wib. 